\title{
Effect of Heat Exposure on Aminophylline-Induced Convulsions in Mice
}

\author{
Rika Ochi, ${ }^{a}$ Katsuya Suemaru, ${ }^{*}, b$ Shinichi Watanabe, ${ }^{b}$ Takumi Yamaguchi, ${ }^{c}$ Kenshi Takechi, ${ }^{a}$ \\ Hiromu KAWASAKI, ${ }^{a}$ and Hiroaki ARAKI ${ }^{b}$ \\ ${ }^{a}$ Department of Clinical Pharmaceutical Science, Graduate School of Medicine, Dentistry and Pharmaceutical Sciences, \\ Okayama University; 1-1-1 Tsushima-naka, Okayama 700-8530, Japan: ${ }^{b}$ Department of Clinical Pharmacology and \\ Pharmacy, Ehime University Graduate School of Medicine; Toon, Ehime 791-0295, Japan: and ${ }^{c}$ Department of Clinical \\ Pharmaceutical Science, Matsuyama University; Matsuyama, Ehime 790-8578, Japan.
}

Received November 2, 2010; accepted February 8, 2011; published online February 16, 2011

\begin{abstract}
Theophylline-associated convulsions are frequently exacerbated by fever, but the mechanisms behind it are still not completely understood. We investigated whether $N$-methyl-D-aspartic acid (NMDA) and gamma aminobutyric acid (GABA) receptors are involved in aminophylline (theophylline-2-ethylenediamine)-induced convulsions that are augmented by heat exposure-induced hyperthermia in mice. Mice exposed to $33^{\circ} \mathrm{C}$ temperatures for $2 \mathrm{~h}$ had significantly increased body temperature $\left(0.94{ }^{\circ} \mathrm{C}\right)$. Heat exposure significantly decreased time required for the onset of convulsions induced by an intraperitoneal (i.p.) injection of aminophylline (300 $\mathrm{mg} / \mathrm{kg})$. The shortened time for onset of convulsions was blocked by the NMDA receptor antagonist dizocilpine $(0.1$, $0.3 \mathrm{mg} / \mathrm{kg}$, i.p.). However, the $\mathrm{GABA}_{\mathrm{A}}$ receptor agonist muscimol $(1,2 \mathrm{mg} / \mathrm{kg}$, i.p.) did not have any effect. The pro-convulsant action of NMDA $\left(100-125 \mathrm{mg} / \mathrm{kg}\right.$, i.p.) was enhanced by the heat exposure of $33{ }^{\circ} \mathrm{C}$. However, the pro-convulsant actions of picrotoxin $\left(3-4 \mathrm{mg} / \mathrm{kg}\right.$, i.p.), a $\mathrm{GABA}_{\mathrm{A}}$ receptor antagonist, were not affected by increased temperatures. These results suggest that NMDA receptors in the brain play a role in aminophyllineinduced convulsions, which are augmented by heat exposure-induced hyperthermia in mice.
\end{abstract}

Key words theophylline; convulsion; hyperthermia; gamma aminobutyric acid $_{\mathrm{A}}$ receptor; $N$-methyl-D-aspartic acid receptor

Theophylline is a very potent central nervous system (CNS) stimulant, and one of the serious adverse effect of theophylline toxicity is the development of convulsions. Several reports have shown that theophylline occasionally induces convulsions in pyrexic asthma patients, even at therapeutic doses. $^{1,2)}$ For this reason if fever occurs, it is recommended that the dosage of theophylline be reduced (or administration of the drug ceased). ${ }^{3)}$

Gamma aminobutyric acid (GABA) and glutamic acid are major inhibitory and excitatory neurotransmitters, respectively. It is now widely accepted that increased seizure susceptibility may be caused by an abnormality in central neurotransmitter systems such as impaired inhibitory transmission (through GABA), excessive excitatory transmission (through glutamate) or through an imbalance between neuronal excitatory and inhibitory pathways. ${ }^{4)}$ We have shown in mice that the benzodiazepine receptor agonist diazepam protects against theophylline-associated convulsions, and that the anticonvulsant action of diazepam is diminished by pyrexia induced by Brewer's yeast. ${ }^{5)}$ These results indicate the possible involvement of benzodiazepine receptors as a mechanism through which the convulsions in mice with fever and inflammation may be augmented. However, the precise mechanisms of the pro-convulsant effect of theophylline underlying pyrexia are not yet fully understood.

Hyperthermia induced by increasing the ambient external temperature is known to induce rapid elevation of body temperature, and produce a fever-like whole-body hyperthermia in experimental animals where it has been used to study the mechanism of febrile convulsions. ${ }^{6}$ Studies using these models have shown that GABA and $N$-methyl-D-aspartic acid (NMDA) receptors play an important role in hyperthermiainduced convulsions and it has been reported that the $\mathrm{GABA}_{\mathrm{A}}$ receptor agonist muscimol and the NMDA receptor antagonist dizocilpine suppress the induction of febrile con- vulsions in rats. ${ }^{7,8)}$

To determine the pro-convulsant effects of theophylline in the presence of fever, we investigated whether the $\mathrm{GABA}_{\mathrm{A}}$ receptor agonist muscimol and the NMDA receptor antagonist dizocilpine had an effect on aminophylline-induced convulsions in the presence of heat exposure-induced hyperthermia. Aminophylline (theophylline-2-ethylenediamine) is a water-soluble theophylline compound with ethylenediamine. It is well documented that the CNS-stimulant properties of aminophylline are due to its theophylline component because ethylenediamine has no convulsive effects. ${ }^{9)}$ In addition, to clarify the effect of hyperthermia, changes in the threshold of convulsion induced by the $\mathrm{GABA}_{\mathrm{A}}$ receptor antagonist picrotoxin and the NMDA receptor agonist NMDA were also investigated.

\section{MATERIALS AND METHODS}

Animals Male ddY mice (6-7 weeks; SLC Co., Ltd., Shizuoka, Japan) were housed in groups of five per plastic cage $(18 \times 44 \times 27 \mathrm{~cm})$ in a room maintained at $23 \pm 1^{\circ} \mathrm{C}$ under a 12-h/12-h light/dark cycle $(7 \mathrm{am}-7 \mathrm{pm}$, respectively). All experimental protocols were conducted in accordance with the Guidelines of the Ethics Review Committee for Animal Experimentation at the Ehime University Medical School.

Drugs The drugs dizocilpine maleate, muscimol, picrotoxin, NMDA (Sigma-Aldrich, St. Louis, MO, U.S.A.) and aminophylline (Neophylline, Eisai Co., Tokyo, Japan) were obtained commercially. Prior to administration, the drugs were dissolved in saline, and then injected via an intraperitoneal (i.p.) route at a volume of $0.1 \mathrm{ml}$ per $10 \mathrm{~g}$ body weight.

Hyperthermia Induced by Heat Exposure Experiments were carried out in a room maintained at $23 \pm 1^{\circ} \mathrm{C}$. During heat stress experiments the mice were exposed to 
heat stress by placing them in an incubator (MIR-152, Sanyo, Tokyo, Japan) at $33^{\circ} \mathrm{C}$ or $38^{\circ} \mathrm{C}$ (relative humidity, $40-50 \%$ ) for $2 \mathrm{~h}$. A digital thermometer was inserted rectally to measure the internal temperature of each animal before commencing the experiments and then $2 \mathrm{~h}$ after exposure to the heat.

Aminophylline-Induced Convulsions An initial experiment to determine the optimal dose of aminophylline required to induce convulsions in mice housed exposed at various temperatures was conducted. The mice received a single i.p. injection of aminophylline $(50-350 \mathrm{mg} / \mathrm{kg}$; increasing by $50 \mathrm{mg}$ increments) and were then housed for $2 \mathrm{~h}$ in cages at 23,33 or $38^{\circ} \mathrm{C}$. The mice were then observed for $60 \mathrm{~min}$, and the frequency of clonic convulsions and the time until the first clonic convulsion were recorded. In mice that did not show convulsions during the observation period of $60 \mathrm{~min}$, for the purpose of data analyses the time taken to produce a convulsion was recorded as $60 \mathrm{~min}$.

Effect of Muscimol and Dizocilpine on AminophyllineInduced Convulsions Once the dose of aminophylline required to produce clonic convulsions in all mice was determined, we next sought to investigate whether muscimol and dizocilpine treatment had any impact on aminophylline-induced convulsions. At room temperature $\left(23^{\circ} \mathrm{C}\right)$, the mice were injected with a single i.p. dose of muscimol $(1,2 \mathrm{mg} /$ $\mathrm{kg})$ or dizocilpine $(0.1,0.3 \mathrm{mg} / \mathrm{kg})$. Two-hours later the mice were then injected with aminophylline $(350 \mathrm{mg} / \mathrm{kg}$ ) and the frequency and time to convulsion were recorded. The rectal temperature for each animal was measured using a digital thermometer before and $2 \mathrm{~h}$ after the treatments. In the experiment focusing on heat exposure $\left(33^{\circ} \mathrm{C}\right)$, the mice were injected with aminophylline $(300 \mathrm{mg} / \mathrm{kg})$. In this experiment, two saline control groups were also present, one maintained at $33^{\circ} \mathrm{C}$ and another group maintained at $23^{\circ} \mathrm{C}$.

Convulsions Induced by Picrotoxin and NMDA To examine changes in the threshold of convulsion by heat exposure, the mice endured 23 or $33^{\circ} \mathrm{C}$ heat exposure for $2 \mathrm{~h}$. The mice were then treated with the $\mathrm{GABA}_{\mathrm{A}}$ receptor agonist picrotoxin $(3.5,4,6 \mathrm{mg} / \mathrm{kg})$ or the NMDA receptor agonist NMDA $(100,125 \mathrm{mg} / \mathrm{kg})$. The frequency of convulsions and the time taken to produce clonic convulsions were measured for $60 \mathrm{~min}$.

Measurement of Serum Concentrations of Theophylline To examine the effect of aminophylline on circulating theophylline, blood was collected from 3 groups of animals. For the first group, the mice were maintained at room temperature $\left(23^{\circ} \mathrm{C}\right)$ and decapitated $30 \mathrm{~min}$ after being treated with aminophylline $(50,100,200 \mathrm{mg} / \mathrm{kg})$. To examine the effect of hyperthermia, two additional experimental groups were also compared. In this setting the mice were injected with aminophylline treatment $(100 \mathrm{mg} / \mathrm{kg}$, i.p. $)$ and then maintained at $23^{\circ} \mathrm{C}$ or $33^{\circ} \mathrm{C}(n=8)$. For these groups, the mice were decapitated 20,30 and $40 \mathrm{~min}$ after the 2-h incubation period. For all three groups, blood was collected and the serum was isolated according to the following methodology. The blood was centrifuged for $3 \mathrm{~min}$ at $11500 \mathrm{rpm}$ and $20-\mu \mathrm{l}$ of serum was added to $200 \mu \mathrm{l}$ methanol containing a theobromine internal standard $(100 \mu \mathrm{l} / \mathrm{ml})$ and mixed for $30 \mathrm{~s}$. After centrifugation at $10000 \mathrm{rpm}$ for $5 \mathrm{~min}, 20 \mu \mathrm{l}$ supernatant were injected into a high-performance liquid chromatography (HPLC) system. Detection was carried out at $280 \mathrm{~nm}$.

Statistical Analyses Data are expressed as mean \pm stan- dard error (S.E.M.). The time of onset of clonic convulsion was analyzed using Kruskal-Wallis followed by Steel-Dwass test for multiple comparison or Mann-Whitney test for two group comparison. The frequency of clonic convulsion was assessed for significance for independence by the chisquared test. The data of body temperature was analyzed using one-way analysis of variance (ANOVA), and Tukey's test or Dunnett's test was used for the post-hoc multiple comparison. Where $p<0.05$ data was considered significant.

\section{RESULTS}

Effect of Heat Exposure on the Convulsant Effect of Aminophylline Two hours of heat exposure increased the body temperature of mice in a temperature-dependent manner (Fig. 1). Mice exposed to $33^{\circ} \mathrm{C}$ temperatures had significantly increased body temperature $\left(0.94^{\circ} \mathrm{C}\right)$. At room temperature $\left(23^{\circ} \mathrm{C}\right)$, aminophylline $(250-350 \mathrm{mg} / \mathrm{kg})$ dose-dependently induced clonic convulsions and shortened the time of onset of convulsions in mice (Fig. 2). The dose-response curves showed that the frequency and time of convulsion onset were greater and induced sooner, respectively, by heat exposure $\left(33,38^{\circ} \mathrm{C}\right)$. In particular, the heat exposure of $38^{\circ} \mathrm{C}$ markedly decreased to time of convulsion onset induced by aminophylline, but there was no dose dependency with respect to the frequency of convulsions. Thus, $33^{\circ} \mathrm{C}$ was selected as the temperature for subsequent experiments.

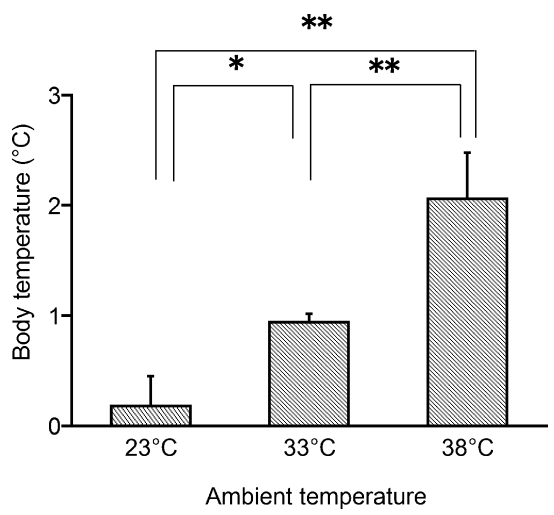

Fig. 1. Changes in Body Temperature after Heat Exposure in Mice

Mice were kept at ambient temperature $\left(23,33,38^{\circ} \mathrm{C}\right)$. The rectal temperature of each mouse was recorded $2 \mathrm{~h}$ after heat exposure. The column represents the mean increase in rectal temperature with S.E.M. $(n=5-12), * p<0.05$, $* * p<0.01$ (ANOVA followed by Tukey's test)
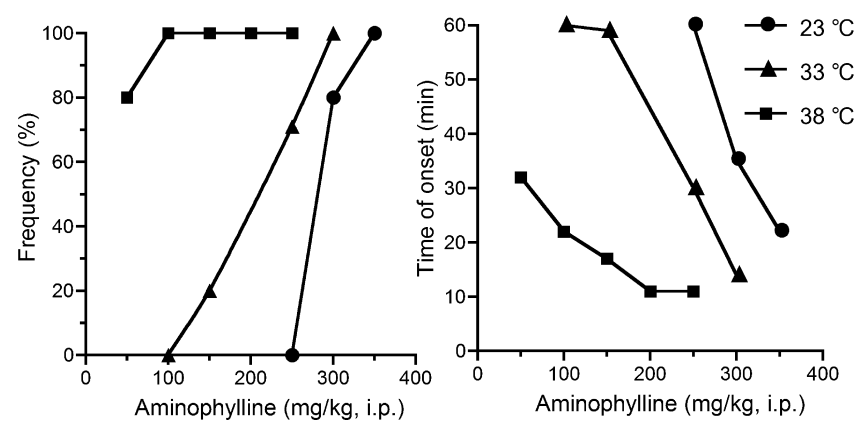

Fig. 2. Effect of Heat Exposure on the Convulsant Action of Aminophylline in Mice

Mice were kept at ambient temperature $\left(23,33,38^{\circ} \mathrm{C}\right)$ for $2 \mathrm{~h}$. Each point represents the frequency $(\%)$ and the time until onset $(\mathrm{min})$ of aminophylline-induced convulsions $(n=5-12)$. 
Effect on Serum Concentrations of Theophylline We investigated the effect of heat exposure $\left(23^{\circ} \mathrm{C}\right.$ or $\left.33^{\circ} \mathrm{C}\right)$ on serum concentrations of theophylline in animals treated with quantities of aminophylline which did not produce convulsions $(50-200 \mathrm{mg} / \mathrm{kg})$. When animals were maintained at $23{ }^{\circ} \mathrm{C}$ (Fig. 3A), blood samples were collected $30 \mathrm{~min}$ after treatment with aminophylline $(50,100,200 \mathrm{mg} / \mathrm{kg})$, revealing that the serum concentrations of theophylline increased in a dose-dependent manner. However, relative to $23^{\circ} \mathrm{C}$, the $33^{\circ} \mathrm{C}$ heat exposure (Fig. 3B) had no effect on serum concentrations of theophylline when blood samples were collected 20, 30 and $40 \mathrm{~min}$ after the treatment with aminophylline $(100 \mathrm{mg} / \mathrm{kg})$.

Effect of Dizocilpine and Muscimol on AminophyllineInduced Convulsions Initially, the effect of dizocilpine and muscimol was investigated at $23^{\circ} \mathrm{C}$ (Table 1). The body temperature of control mice was $36.8 \pm 0.1{ }^{\circ} \mathrm{C}$. The body temperature of the mice treated with dizocilpine $(0.1,0.3 \mathrm{mg} /$ $\mathrm{kg}$ were $36.5 \pm 0.1,36.2 \pm 0.1^{\circ} \mathrm{C}$ respectively), and there was no significant difference in compared to the control. However, muscimol $(1,2 \mathrm{mg} / \mathrm{kg})$ significantly decreased body temperature to $34.2 \pm 0.3$ and $33.8 \pm 0.5^{\circ} \mathrm{C}$, meaning a loss of $-2.2 \pm 0.2$ and $-2.7 \pm 0.5^{\circ} \mathrm{C}$, respectively, $2 \mathrm{~h}$ after treatment $(p<0.01)$.

Table 1 shows the effect of dizocilpine and muscimol on aminophylline-induced convulsions at $23^{\circ} \mathrm{C}$. The mice were
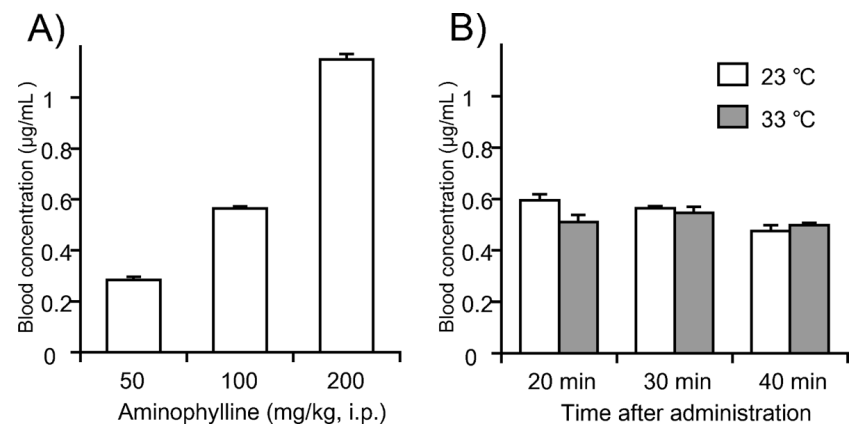

Fig. 3. Effect of Heat Exposure on Serum Concentrations of Theophylline in Mice

Mice were administere $50-200 \mathrm{mg} / \mathrm{kg}$ aminophylline (A) at $23{ }^{\circ} \mathrm{C}$ and blood samples were collected $30 \mathrm{~min}$ after treatment $(n=6-8)$. A separate cohort of mice were maintained at $23{ }^{\circ} \mathrm{C}$ and $33{ }^{\circ} \mathrm{C}$ for $2 \mathrm{~h}$ (B) immediately after the administration of aminophylline $(100 \mathrm{mg} / \mathrm{kg})$ and blood samples were collected 20,30 and $40 \mathrm{~min}$ after treatments $(n=8)$. Data represent the mean with S.E.M.

Table 1. Effect of Dizocilpine and Muscimol on Aminophylline-Induced Convulsions in Mice

\begin{tabular}{lcccc}
\hline \hline \multirow{2}{*}{ Drug } & & $\begin{array}{c}\text { Changes } \\
\text { of body }\end{array}$ & \multicolumn{2}{c}{$\begin{array}{c}\text { Aminophylline-induced } \\
\text { convulsion }\end{array}$} \\
\cline { 4 - 5 } & & $\begin{array}{c}\text { temperature } \\
\left({ }^{\circ} \mathrm{C}\right)\end{array}$ & $\begin{array}{c}\text { Frequency } \\
(\%)\end{array}$ & $\begin{array}{c}\text { Time of onset } \\
(\mathrm{min})\end{array}$ \\
\hline Saline & & $0.3 \pm 0.1$ & 100 & $16.6 \pm 2.2$ \\
Dizocilpine & 0.1 & $0.4 \pm 0.2$ & 100 & $17.5 \pm 1.1$ \\
Muscimol & 0.3 & $0.2 \pm 0.1$ & 100 & $22.6 \pm 3.5$ \\
& 1 & $-2.2 \pm 0.2 * *$ & 100 & $22.6 \pm 3.8$ \\
& 2 & $-2.7 \pm 0.5 * *$ & 88 & $27.2 \pm 6.5$ \\
\hline
\end{tabular}

Mice were administered dizocilpine, muscimol and saline at room temperature $\left(23^{\circ} \mathrm{C}\right)$. The rectal temperature of each mouse was recorded before and $2 \mathrm{~h}$ after the treatments. Aminophylline $(350 \mathrm{mg} / \mathrm{kg}$, i.p.) was administered $2 \mathrm{~h}$ after the treatments. Data represent the frequency (\%) and the mean time until onset (min) of convulsions with S.E.M. $(n=8) . * * p<0.01$ (ANOVA followed by Dunnett's test). administered $350 \mathrm{mg} / \mathrm{kg}$ aminophylline, causing clonic convulsions in $100 \%$ of mice. The convulsions induced by aminophylline were not significantly affected by dizocilpine $(0.1,0.3 \mathrm{mg} / \mathrm{kg})$ or muscimol $(1,2 \mathrm{mg} / \mathrm{kg})$. However, heat exposure at $33^{\circ} \mathrm{C}$ (Fig. 4) slightly increased the frequency and significantly $(p<0.05)$ shortened the onset of convulsions induced by aminophylline $(300 \mathrm{mg} / \mathrm{kg})$. The decreased time of onset of convulsions was significantly blocked by the NMDA receptor antagonist dizocilpine $(0.1,0.3 \mathrm{mg} / \mathrm{kg}, p<0.05)$. However, the $\mathrm{GABA}_{\mathrm{A}}$ receptor agonist muscimol $(1,2 \mathrm{mg}$ / $\mathrm{kg}$ ) showed no significant effect.

Effect of Heat Exposure on Convulsions Induced by Chemical Convulsants Picrotoxin $(3.5,4,6 \mathrm{mg} / \mathrm{kg})$ dosedependently induced clonic convulsions and decreased the time until convulsion onset at $23^{\circ} \mathrm{C}$. The pro-convulsant action of picrotoxin was not affected by heat exposure of $33^{\circ} \mathrm{C}$ (Fig. 5). NMDA (100, $\left.125 \mathrm{mg} / \mathrm{kg}\right)$ dose-dependently produced clonic convulsions at room temperature $\left(23^{\circ} \mathrm{C}\right)$. Heat exposure at $33^{\circ} \mathrm{C}$ significantly increased $(p<0.05)$ the
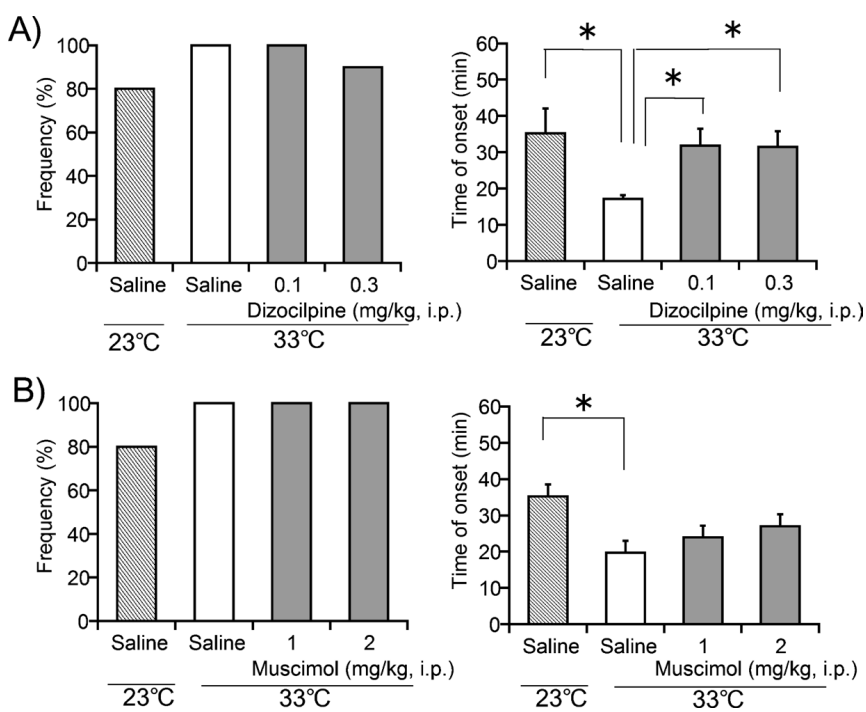

Fig. 4. Effect of Dizocilpine and Muscimol on the Aggravation of Aminophylline-Induced Convulsions in Mice with Hyperthermia

Mice were maintained at ambient temperatures of $23^{\circ} \mathrm{C}$ or $33^{\circ} \mathrm{C}$ immediately after the administration of dizocilpine (A), muscimol (B) or saline. Aminophylline $(300 \mathrm{mg} / \mathrm{kg}$ ) was then administered $2 \mathrm{~h}$ after the treatments with dizocilpine or muscimol. Each column represents the frequency (\%) and the mean time of onset of convulsions (min) with S.E.M. $(n=10) . * p<0.05$ compared with the saline-treated control group at an ambient temperature of $33{ }^{\circ} \mathrm{C}$ (Kruskal-Wallis followed by Steel-Dwass test or Mann-Whitney test).
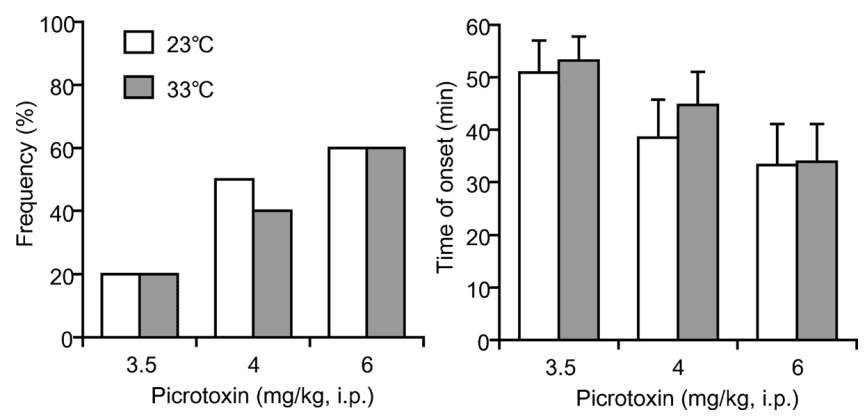

Fig. 5. Effect of Heat Exposure on Picrotoxin-Induced Convulsions in Mice

Mice were administered picrotoxin $(3.5,4,6 \mathrm{mg} / \mathrm{kg}) 2 \mathrm{~h}$ after heat exposure (23, $\left.33^{\circ} \mathrm{C}\right)$. Each column represents the mean frequency $(\%)$ and the mean time of onset of convulsions ( $\mathrm{min})$ with S.E.M. $(n=10)$. 

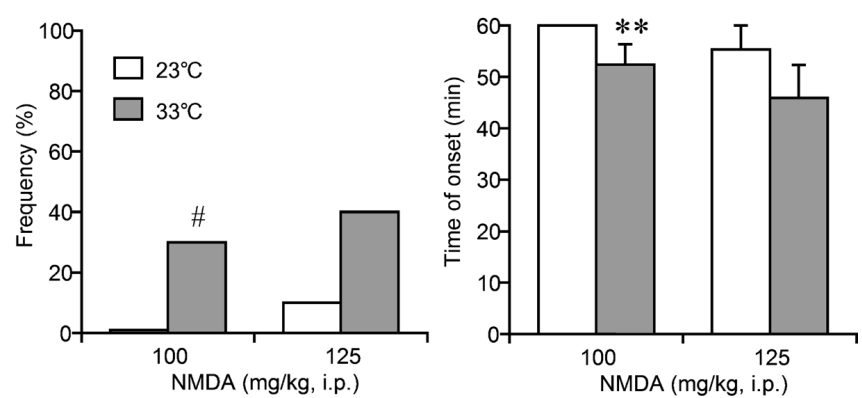

Fig. 6. Effect of Heat Exposure on NMDA-Induced Convulsions in Mice

Mice were administered NMDA $(100,125 \mathrm{mg} / \mathrm{kg}) 2 \mathrm{~h}$ after heat exposure (23, $33^{\circ} \mathrm{C}$ ). Each column represents the mean frequency $(\%)$ and the mean time of onset of convulsions ( $\mathrm{min})$ with S.E.M. $(n=18) . \# p<0.05$ (chi-squared test), $* * p<0.01$ (Kruskal-Wallis followed by Mann-Whitney test).

frequency of convulsions induced by NMDA $(100 \mathrm{mg} / \mathrm{kg})$ and significantly shortened $(p<0.01)$ the onset in comparison with these at $23^{\circ} \mathrm{C}$ (Fig. 6).

\section{DISCUSSION}

It has been reported that hyperthermia induced by heat exposure to moist heated air $\left(50^{\circ} \mathrm{C}\right)$ can cause convulsions in experimental animals. ${ }^{10}$ ) These hyperthermia-induced convulsions in experimental animals have been used as a model to study the mechanisms of febrile convulsions. In the present study, exposure to $33^{\circ} \mathrm{C}$ and $38^{\circ} \mathrm{C}$ increased the body temperature of mice and lowered the threshold of convulsion induced by aminophylline in a temperature-dependent manner. At $38^{\circ} \mathrm{C}$, the convulsions were markedly exacerbated, but there was no increase in the frequency. In contrast, exposure to $33^{\circ} \mathrm{C}$ increased the frequency of convulsions and shortened the time of onset. Therefore, in the present study, the hyperthermia-induced by exposure to $33^{\circ} \mathrm{C}$ was used to investigate the possible mechanism of how convulsions induced by aminophylline are augmented by heat exposure.

It is well known that serum concentrations of theophylline correlate well with convulsions. Although the effect of pyrexia on the pharmacokinetics of theophylline has not been clearly established, it has been reported that fever occasionally changes theophylline pharmacokinetics. For example, a decreased clearance of theophylline has been reported in childhood asthma patients with febrile respiratory infection. ${ }^{11)}$ However, in the present study using mice, any significant change in the theophylline concentrations was not observed after $33^{\circ} \mathrm{C}$ heat exposure.

Benzodiazepines are widely used as anticonvulsants against theophylline-induced convulsions. It is well known that benzodiazepines and barbiturates are agonists for the $\mathrm{GABA}_{\mathrm{A}}$ receptor complex. Studies on experimental animals have also shown that diazepam and phenobarbital antagonize theophylline-induced convulsions. ${ }^{4,12,13)}$ As for the $\mathrm{GABA}_{\mathrm{A}}$ receptor agonist, Amabeoku has reported that muscimol, at a dose of $2 \mathrm{mg} / \mathrm{kg}$, decreased theophylline-induced convulsions in female albino mice. ${ }^{13)}$ Our previous study showed that diazepam blocked aminophylline-induced convulsions, but the $\mathrm{GABA}_{\mathrm{A}}$ receptor agonist muscimol $(1-4 \mathrm{mg} / \mathrm{kg})$ had no effect in male ddY mice, when the drugs are administered 30 min prior to aminophylline. ${ }^{5)}$ Moreover, in the present study, we confirmed that muscimol $(1,2 \mathrm{mg} / \mathrm{kg}$, administered
$2 \mathrm{~h}$ before the aminophylline) had no effect on the induction of convulsions. Several studies using various models of convulsions have shown the different action of benzodiazepines and the $\mathrm{GABA}_{\mathrm{A}}$ receptor agonist. ${ }^{14,15)} \mathrm{A}$ major reason for these differing results may relate to sex or strain differences in GABA-benzodiazepine receptor coupling. ${ }^{16,17)}$ On the other hand, the NMDA receptor antagonists dizocilpine and ketamine have been reported to be ineffective in antagonizing convulsions induced by aminophylline in rats and mice. ${ }^{18)}$ Our previous report ${ }^{5)}$ and the present study showed that aminophylline-induced convulsions are not affected by dizocilpine, either when the drugs are administered $30 \mathrm{~min}$ or $2 \mathrm{~h}$ before the aminophylline.

In the present study, the $\mathrm{GABA}_{\mathrm{A}}$ receptor agonist muscimol markedly decreased the body temperature of animals held at an ambient temperature of $23^{\circ} \mathrm{C}$, which is consistent with previous studies. ${ }^{19)}$ However, the NMDA receptor antagonist dizocilpine had no effect on body temperature. The frequency and time of onset of aminophylline-induced convulsions were not affected by dizocilpine and muscimol. On the other hand, at $33{ }^{\circ} \mathrm{C}$ dizocilpine blocked the decrease in time of onset of aminophylline-induced convulsions. Muscimol slightly increased the decrease in time of onset of aminophylline-induced convulsions, but there was no statistically significant difference. These results suggested that NMDA receptors play an important part in the sensitization to aminophylline-induced convulsions by hyperthermia. This hypothesis was further supported by the lower threshold for NMDA-induced convulsions in mice with hyperthermia-induced by heat exposure. Hyperthermia is known to increase the release of glutamate in the brain. ${ }^{20}$ Therefore, activation of NMDA receptors by increased extracellular glutamate during hyperthermia may be involved in the aggravation of aminophylline-induced convulsions.

We have shown in mice that the anticonvulsant action of diazepam against aminophylline-induced convulsion is diminished by pyrexia induced by Brewer's yeast ${ }^{5)}$ which suggests an involvement of benzodiazepine receptors whereby convulsions associated with fever and inflammation are aggravated. Hyperthermia-induced seizures in immature rats (10 - 20 d postnatal) have been used as a model of febrile seizures, and have been reported to involve a depression of GABAergic neurotransmission and an activation of glutamic acid neurotransmission as a possible mechanisms underlying hyperthermia-induced seizures. ${ }^{7,8,21)}$ The results of the present study suggest that the glutamatergic system in the brain maybe be responsible for the decreased convulsion threshold of theophylline by heat exposure-induced hyperthermia in adult mice. Recently, higher sensitivity of inhibitory synaptic function relating GABAergic neurotransmission to hyperthermia in immature compared with mature rats has been reported. ${ }^{22)}$ These findings indicate that age-dependent changes of neuronal neurotransmission are involved in hyperthermiainduced seizures. Therefore, further studies will be necessary to clarify the precise mechanisms of how theophylline-associated convulsions are augmented during fever.

Acknowledgements This work was supported by the Japanese Health Science Foundation and a Grant-in-Aid for Scientific Research (No. 22590085) from the Ministry of Education, Culture, Sports, Science and Technology of Japan. 


\section{REFERENCES}

1) Korematsu S., Miyahara H., Nagakura T., Suenobu S., Izumi T., Pediatr. Int., 50, 95-98 (2008).

2) Zaccara G., Muscas G. C., Messori A., Drug Saf., 5, 109-151 (1990).

3) Nishima S., Arerugi, 55, 781-790 (2006).

4) Sierra-Paredes G., Sierra-Marcuno G., CNS Neurol. Disord. Drug Targets, 6, 288-300 (2007).

5) Ochi R., Suemaru K., Kawasaki H., Araki H., Acta Med. Okayama, 63, 273-280 (2009).

6) Morimoto T., Nagao H., Sano N., Takahashi M., Matsuda H., Epilepsia, 32, 289-293 (1991)

7) Morimoto T., Kida K., Nagao H., Yoshida K., Fukuda M., Takashima S., Brain Res. Dev. Brain Res., 84, $204-207$ (1995).

8) Fukuda M., Morimoto T., Nagao H., Kida K., Brain Res. Dev. Brain Res., 104, 197-199 (1997).

9) Chu N. S., Epilepsia, 22, 85-94 (1981).

10) Fukuda M., Morimoto T., Suzuki Y., Shinonaga C., Ishida Y., Brain Dev., 29, 644-648 (2007).

11) Toba T., Kurosaki T., Ohta F., Tamai K., Ikegami H., Saitoh Y., Ma- tsuka Y., Makino K., Asai T., Arerugi, 43, 113-119 (1994).

12) Jaishree J., Kumaresan S., Sudha S., David J., Kulkarni C., Pol. J. Pharmacol., 55, 559-564 (2003).

13) Amabeoku G. J., Gen. Pharmacol., 32, 365-372 (1999).

14) Czuczwar S. J., Chmielewska B., Turski W. A., Kleinrok Z., Neuropharmacology, 23, 159-163 (1984).

15) Gernert M., Löscher W., Eur. J. Pharmacol., 432, 35-41 (2001).

16) Jung M. E., Wallis C. J., Gatch M. B., Lal H., J. Pharmacol. Exp. Ther., 291, 576-582 (1999).

17) Wilks L., File S. E., Martin I. L., Psychopharmacology (Berlin), 93, 127-132 (1987).

18) Ray A., Gulati K., Anand S., Vijayan V. K., Indian J. Exp. Biol., 43, $849-853$ (2005).

19) Biswas S., Poddar M. K., Methods Find. Exp. Clin. Pharmacol., 10, 747 -749 (1988).

20) Morimoto T., Nagao H., Yoshimatsu M., Yoshida K., Matsuda H., Epilepsia, 34, 447-452 (1993).

21) Qu L., Leung L. S., J. Neurochem., 106, 2158-2169 (2008).

22) Qu L., Leung L. S., J. Neurosci. Res., 87, 2773-2785 (2009). 